\title{
Exploitation of Two Consortiums in Microbial Degradation and Decolorization of Remazol Black and Acid Orange
}

\section{Shah $\mathbf{M}^{*}$}

Industrial Waste Water Research Laboratory, Division of Applied \& Environmental Microbiology, Environmental Technology Limited, Gujarat, India

\begin{abstract}
Different soil samples were collected from effluent treatment plants were used as a source for the isolation of 16 morphologically distinct bacteria capable of decolourising textile dye, Acid orange. Decolourisation assay was performed using two textile dyes - Acid oragne and emazol black to screen for high dye decolourising bacterial isolates. 5 Bacterial isolates showed high decolourisation of Acid orange and a consortium of these 5 colonies called A was developed. 3 Bacterial isolates showed high decolourisation of Remazol black and a consortium of these 3 isolates, $\mathrm{B}$, was developed. The screened bacterial isolates were identified as Pseudomonas sp., Alcaligens $s p$., Rhodococcus sp., Stenotrophomonas sp., Proteobacterium sp., and Bacillus sp. by $16 \mathrm{~S}$ rDNA analysis. A exhibited high decolourisation percentage of $200 \mathrm{mg} / \mathrm{l}$ of Acid orange in the presence of anhydrous sodium acetate under static condition at $\mathrm{pH} 7$ and temperature of $40^{\circ} \mathrm{C}$ within 48 hours. B showed high decolourisation of $200 \mathrm{mg} / \mathrm{l}$ of Remazol black in the presence of galactose and a combination of straw and beef extract under static condition at $\mathrm{pH} 7$ and temperature of $30^{\circ} \mathrm{C}$ within 48 hours. LC-MS analysis of the degraded product of Acid orange by A showed the presence of 1-\{3-amino 5- [(aminoxy) sulphonyl] phenyl\} ethanol and 7, 8-amino-3-[(aminoxy) sulphonyl] napthalen1-ol. LC-MS analysis of the degraded product of Remazol black by B showed the presence of 1.1'-diazene-1,2diyldinapthlen-2-ol and sodium-4-amino-naphthalene-1-sulphonate.
\end{abstract}

Keywords: Pseudomonas; Alcaligens; Stenotrophomonas; Rhodococcus; Remazol black; Acid orange

\section{Introduction}

The growth of the world population, the development of various industries, and the use of fertilizers and pesticides in modern agriculture has overloaded not only the water resources but also the atmosphere and the soil with pollutants [1-4]. In the last few decades the handling of wastewater appeared to be one of the most important. Textile industry which is one of the largest water consumers in the world produces the wastewater comprising of various recalcitrant agents such as dye, sizing agents and dying aid. Therefore it has to be really concerned in releasing these types of wastewater to the environment. In the disposal of textile wastewater, color is of very important due to the aesthetic deterioration as well as the obstruction of penetration of dissolved oxygen and sun light into natural water bodies [5-9]. The degradation of the environment due to the discharge of polluting wastewater from industrial sources is a real problem in several countries. This situation is even worse in developing countries like India where little or no treatment is carried out before the discharge [10]. In spite of the many steps taken to maintain and improve the quality of surface and groundwater, the quantities of wastewater generated by these industries continue to increase and municipalities and industries are confronted with an urgent need to develop safe and feasible alternative practices for wastewater management. Bioremediation is a pollutioncontrol technology that uses natural biological species to catalyze the degradation or transformation of various toxic chemicals to less harmful forms. Xenobiotic compounds are not naturally available and hence the locally occurring microorganisms cannot readily degrade them. Hazardous materials may render harm to humans, livestock, wildlife, crops or native plants through handling, ingestion, application to land or other distributions of the contaminated materials into the environment. The textile industry leaves about $50 \%$ of the textile azo dyes in free state to be discharged in the factory effluent and eventually to the surrounding environment. Azo compounds constitute the largest and the most diverse group of synthetic dyes and are widely used in a number of industries such as textile, food, cosmetics and paper printing [11]. The reactive azo dyes-containing effluents cause serious environmental pollution. Therefore, industrial effluents containing azo dyes must be treated before discharging into the environment to remove the dye toxicity from textile effluents [12]. Our study deals with the isolation of bacteria, development of mixed bacterial consortium for static degradation of textile dyes, Acid orange and Remazol black. 16S rDNA analysis has been carried out to determine the bacterial isolates. A degradation pathway has been elucidated for these sulphonated azo dyes using bacterial consortium.

\section{Materials and Methods}

\section{Collection and laboratory analysis}

The Effluent sample was collected from the middle point of the area. The Temperature and $\mathrm{pH}$ were determined at the sampling site. The $\mathrm{pH}$ was determined by using $\mathrm{pH}$ meter (Cyber scan $\mathrm{pH}$ meter) and temperature with laboratory thermometer. The sample was transported to laboratory at $4^{\circ} \mathrm{C}$ as in accordance with the standard methods [13]. The physicochemical parameters such as (Colour, Biological Oxidation Demand (BOD) Chemical Oxygen Demand (COD), Total Suspended Solids (TSS), and Total Dissolved Solids (TDS) were determined as soon as the sample was brought to the laboratory. Sample colour was analyzed by spectrophotometer (Shimadzu UV-1700). BOD was

*Corresponding author: Shah M, Industrial Waste Water Research Laboratory, Division of Applied \& Environmental Microbiology, Environmental Technology Limited, Gujarat, India, Tel: 91-9099965504; E-mail: shahmp@uniphos.com

Received August 22, 2014; Accepted August 28, 2014; Published September 04, 2014

Citation: Shah M (2014) Exploitation of Two Consortiums in Microbial Degradation and Decolorization of Remazol Black and Acid Orange. J Pet Environ Biotechnol 5 196. doi:10.4172/2157-7463.1000196

Copyright: (c) 2014 Shah M. This is an open-access article distributed under the terms of the Creative Commons Attribution License, which permits unrestricted use, distribution, and reproduction in any medium, provided the original author and source are credited. 


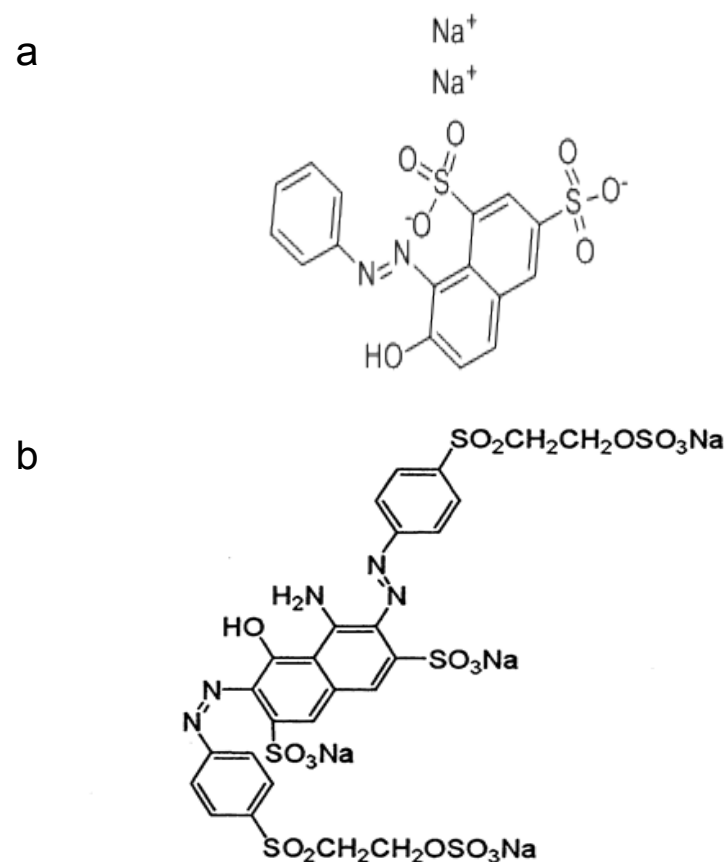

Figure 1: (a)Chemical structure of acid orange dye. (b) Structure of remazol black dye.

determined by employing evaporation method by DO meter while COD was measured by COD instrument directly.

\section{Dyes and chemicals}

The textile dye, Remazol Black and Acid orange was obtained from local textile industry. The stock solution of dyes was filter sterilized and added to the growth medium in the required concentration. All the chemicals used were of analytical grade and procured from Himedia Pvt Limited. The Chemical Structure of Remazol Black and Acid orange is shown in Figure 1.

\section{Isolation and screening}

The Textile Effluent was collected in sterile collection tubes from the sludge and wastewater of the ditches at industrial site. The sample collected from the textile mill was screened for Acid orange decolorizing bacterial strains by inoculating $10 \mathrm{ml}$ of sludge solution into $250 \mathrm{ml}$. Erlenmeyer flask containing $100 \mathrm{ml}$ nutrient broth $\left(\mathrm{gL}^{-1}\right.$ Peptone-5, Meat extract-1, Yeast extract-2, NaCl-5, pH-7). The flasks were incubated at $35^{\circ} \mathrm{C}$ under shaking conditions (140 rpm). After 48 $\mathrm{h}$ of incubation, $1.0 \mathrm{ml}$. of the culture broth was appropriately diluted and plated on Nutrient Agar containing $20 \mathrm{mg} \mathrm{L}^{-1}$ Acid orange. The Morphologically distinct bacterial isolates showing clear zones around their colonies due to decolorization of dye were selected for further studies. The pure culture stocks of these isolates were stored at $4^{\circ} \mathrm{C}$ on Nutrient Agar slopes containing $1000 \mathrm{mg} \mathrm{L}^{-1}$ of Acid orange. These isolates were screened for their ability to decolorize Acid orange in liquid culture. The Screening process in liquid media was carried out by inoculating a loop full of cultures exhibiting clear zones into Nutrient broth containing Acid orange under static conditions. After $24 \mathrm{~h}$ of incubation, $1 \mathrm{ml}$ of cell suspension was transferred to fresh nutrient broth containing Acid orange to screen the strains with color removing ability. The Screening procedure in liquid medium was continued until complete decolorization of broth. A small amount of decolorized broth was transferred to nutrient agar plates containing Acid orange (50 mg $\left.\mathrm{L}^{-1}\right)$. The bacterial isolate which tolerated higher concentration of the Azo dye was isolated by streaking plate method.

\section{Isolation of DNA from dye degrading bacterial isolates}

Genomic DNA from each of the screened bacteria was isolated. The presence of DNA was checked by running in agarose gel $(0.8 \%)$ stained with Ethidium Bromide.

\section{Amplification of $16 \mathrm{~S} r$ DNA sequence by polymerase chain reaction}

The reaction mixture of total volume of $30 \mu \mathrm{l}$ consisted of $3 \mu \mathrm{l}$ of $10 \mathrm{X}$ Buffer, $1 \mu \mathrm{l}$ of $10 \mathrm{mM}$ dNTPs, $1 \mu \mathrm{l}$ of $16 \mathrm{~S}$ rDNA primer ( 5 picomole $/ \mu \mathrm{l})$, $3 \mathrm{U} / \mu \mathrm{l}$ of Taq Polymerase, $5 \mu \mathrm{l}$ of template DNA $(280 \mathrm{ng} / \mathrm{ml})$ and $19 \mu \mathrm{l}$ of sterile distilled water. The PCR reaction was set to initial denaturation of $94^{\circ} \mathrm{C}$ for 5 minutes, followed by 35 cycles of denaturation at $94^{\circ} \mathrm{C}$ for one minute, annealing at $55^{\circ} \mathrm{C}$ for one minute, extension at $72^{\circ} \mathrm{C}$ for one minute and final extension at $72^{\circ} \mathrm{C}$ for 10 minutes (17). The amplified products were stained with $0.5 \mu \mathrm{g} / \mathrm{ml}$ Ethidium Bromide and loaded on $0.8 \%$ agarose gel, and the DNA fragments were separated at $100 \mathrm{~V}$ and documented using Launch Doc IFLS software.

\section{Sequencing the amplified product followed by BLAST}

The amplified product was subjected to cycle sequencing to identify the bacterial isolate using ABI $3130 \mathrm{XL}$ (Analyser, USA). The sequence was then subjected for BLAST analysis to identify the bacterial isolate (http://blast.ncbi.nlm.nih.gov/Blast.cgi).

\section{Development of bacterial consortium}

The screened bacterial isolates were cultured in $250 \mathrm{ml}$ Erlenmeyer flask containing nutrient broth medium. A consortium was developed by aseptically transferring $0.1 \mathrm{ml}$ of the suspension of 24 hour grown culture of each individual strain into fresh nutrient broth and incubated for 24 hours at $37^{\circ} \mathrm{C}(54)$. Two consortia were developed-one from the data obtained from decolourisation assay of Acid orange (A), and the other obtained from the decolourisation assay of Remazol black (B).

\section{Decolorization study}

To study the decolorization, used medium was minimal medium containing following ingredients per liter: $\mathrm{KNO}_{3}: 5 \mathrm{~g},\left(\mathrm{NH}_{4}\right)_{2} \mathrm{SO}_{4}: 1 \mathrm{~g}$, $\mathrm{K}_{2} \mathrm{HPO}_{4} \cdot 3 \mathrm{H}_{2} \mathrm{O}: 0.87 \mathrm{~g}, \mathrm{KH}_{2} \mathrm{PO}_{4}: 0.54 \mathrm{~g}, \mathrm{MgSO}_{4} .7 \mathrm{H}_{2} \mathrm{O}: 0.2 \mathrm{~g}, \mathrm{CaCl}_{2} .2 \mathrm{H}_{2} \mathrm{O}$ : $0.02 \mathrm{~g}, \mathrm{FeSO}_{4} .7 \mathrm{H}_{2} \mathrm{O}: 0.01 \mathrm{~g}, \mathrm{MnSO}_{4} \cdot \mathrm{H}_{2} \mathrm{O}: 0.005 \mathrm{~g}$ supplemented with $2.5 \%-10 \% \mathrm{NaCl}$ and dye as sole carbon source.

\section{Effect of different physico-chemical parameters on decolourisation}

Aliquot of $0.1 \mathrm{ml}$ of each consortium (A and B) and each of the bacterial isolates was inoculated into test tubes containing LB Media amended with dyes (Acid red and Mordant black). These test tubes were incubated with different dye concentrations $(50 \mathrm{mg} / \mathrm{l}, 100 \mathrm{mg} / \mathrm{l}$, $200 \mathrm{mg} / \mathrm{l}$ and $400 \mathrm{mg} / \mathrm{l}$ ), under different oxygen conditions (aerobic, anaerobic and static), at different temperatures $\left(10^{\circ} \mathrm{C}, 20^{\circ} \mathrm{C}, 30^{\circ} \mathrm{C}, 40^{\circ} \mathrm{C}\right.$, $50^{\circ} \mathrm{C}$ and $60^{\circ} \mathrm{C}$ ) and at different $\mathrm{pH}(2$ to 9$)$. At various time intervals ( 24 and $48 \mathrm{~h}$ ), the percentage of decolourisation was calculated. Each experiment was repeated for three times and mean value was taken for result analysis

\section{Decolorization measurement}

For decolorization measurement, sample $(1.5 \mathrm{ml})$ of the culture media was taken at different time intervals, well agitated prior to 
sampling (due to the insolubility of dye) and centrifuged at $7500 \mathrm{rpm}$ for $5 \mathrm{~min}$ with a micro refrigerated centrifuge at $20^{\circ} \mathrm{C}$ to separate bacterial cell mass. Decolorization rate was calculated from the difference between initial and final absorbance values at the absorbance maxima of the dye ( $490 \mathrm{~nm}$ ) on a UV-vis spectrophotometer (Shimdzu, Japan). Uninoculated culture media with and without added dyes were used as controls.

\section{Metabolites extraction}

About $100 \mathrm{ml}$ of Acid orange $(200 \mathrm{mg} / \mathrm{l})$ containing LB Media with $0.1 \mathrm{ml}$ of 24 hour grown culture of A was incubated for 24 hours

\begin{tabular}{|c|c|c|c|}
\hline S.No & Parameter & Unit & Effluent \\
\hline $\mathbf{1}$ & Color & - & Dark red \\
\hline $\mathbf{2}$ & Smell & - & pungent \\
\hline $\mathbf{3}$ & Temperature & ${ }^{\circ} \mathrm{C}$ & 38 \\
\hline $\mathbf{4}$ & PH & - & 8.0 \\
\hline $\mathbf{5}$ & TDS & $\mathrm{mg} / \mathrm{l}$ & 7500 \\
\hline $\mathbf{6}$ & TSS & $\mathrm{mg} / \mathrm{l}$ & 2800 \\
\hline $\mathbf{7}$ & COD & $\mathrm{mg} / \mathrm{l}$ & 700 \\
\hline $\mathbf{8}$ & BOD & $\mathrm{mg} / \mathrm{l}$ & 220 \\
\hline
\end{tabular}

Table 1: Physico-chemical characterization of the textile effluent collected from Textile Industries, Ankleshwar.

\begin{tabular}{|c|c|c|}
\hline Sample & $\begin{array}{c}\% \text { Decolorization with Acid } \\
\text { Orange }\end{array}$ & $\begin{array}{c}\% \text { Decolorization with Remazol } \\
\text { Black }\end{array}$ \\
\hline 1 & 38.24 & - \\
\hline 2 & 57.28 & - \\
\hline 3 & 46.56 & 17.36 \\
\hline 4 & 23.68 & 9.6 \\
\hline 5 & 51.04 & 4.18 \\
\hline 6 & 59.52 & 71.17 \\
\hline 7 & 74.88 & - \\
\hline 8 & - & 17.04 \\
\hline 9 & - & - \\
\hline 10 & 23..36 & 36.6 \\
\hline 11 & 40.64 & - \\
\hline 12 & 45.12 & 34.4 \\
\hline 13 & 74.72 & - \\
\hline 14 & 43.04 & 65.27 \\
\hline 15 & 74.72 & - \\
\hline 16 & 87.2 & 69.13 \\
\hline
\end{tabular}

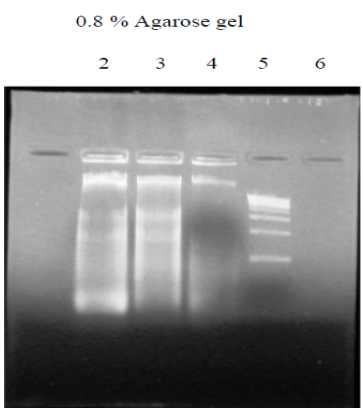

(a) Lane 2- $14-2$ Iane $3-6$ Lane 4.7 Lane $5-1 \mathrm{~kb}$ DNA
$0.8 \%$ Agarose gel

$\begin{array}{llllll}1 & 2 & 3 & 4 & 5\end{array}$

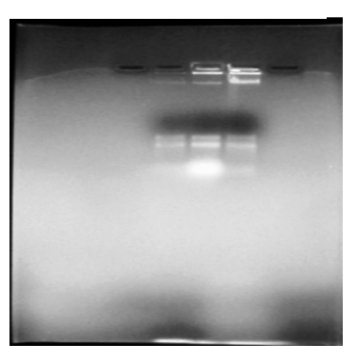

(b)

Lane 2- 13 Lane 3-15
Figure 2: Isolation of DNA and 48 hours. Using a separating funnel, the organic compounds were extracted using equal amount of ethyl acetate from the incubated dye containing culture ( 24 and 48 hour cultures). The ethyl acetate phase was then subjected to evaporation at $78^{\circ} \mathrm{C}$ to obtain a powdery residue of the organic compound (69).

\section{LC MS analysis}

The powdery residue was then dissolved in acetonitrile (HPLC Grade). LC-MS analysis was performed using a Finnigan model Mass Spectrometer (Thermo Electron Corporation, USA) using C-18 column from Waters. The cartridges were conditioned with pure acetonitrile, washed with deionized water ( $0.1 \%$ Formic Acid) and the elution took place with $70 \%$ acetonitrile, containing $0.1 \%$ formic acid. The flow rate was $0.8 \mathrm{ml} / \mathrm{min}$. The ion trap detector with atmospheric pressure electrospray ionization (API-ESI) source used for quantification in negative ionization mode. Operating conditions were dry with temperature of $325^{\circ} \mathrm{C}$, Capillary voltage $3500 \mathrm{~V}$, Nebulizer $14 \mathrm{psi}$, dry gas Helium 5.0 $1 / \mathrm{min}$. Ion trap full scan analyses were conducted from $\mathrm{m} / \mathrm{z}$ 200-1400 with an upper full time of 300 minutes. The nebulizer gas flow and the curtain gas flow (Nitrogen gas) were set at 10 and 8 psi. The ion spray, orifice and ring voltage were set at $+4800,40,+70 \mathrm{~V}$ respectively. Instrumentation control and data acquisitions were performed with data analysis for Mass Spectroscopy (X caliber, USA).

\section{Results}

\section{Characterization of textile effluent}

The effluent sample collected from a small scale Textile Industries, Ankleshwar, Gujarat, India was dark red in color, with pungent smell and $\mathrm{pH}$ of slightly above neutral level and was within the permissible limits (Table 1). The temperature of the effluent was high. Total Suspended Solids (TSS) and Total Dissolved Solids (TDS) in the textile effluent were very high. The solids present in ground water, besides effecting the growth of the plants directly, also affect the soil structure, permeability and aeration, indirectly effecting the plant growth. The Chemical Oxygen Demand (COD) and Biological Oxygen Demand (BOD) values were within the permissible limits in the effluent sample. Different bacterial strains isolated from the textile effluent were screened for their ability to decolorize the textile Azo dye (Toludine Red) and the potential strains were characterized morphologically and biochemically.

\section{Screening for high dye decolourising bacterial isolates and development of bacterial consortium}

Upon serial dilution, 16 morphologically distinct colonies were isolated and named as 1, 2, 3, 4, 5, 6, 7, 8, 9, 10, 11, 12, 13, 14, 15 and 16. Each of these isolates was subjected for dye decolourisation assay. At the end of 48 hours, in the case of Acid orange, isolates 6, 13, 7, 15 and 16 showed more than $70 \%$ decolourisation. Isolates $1,42,10,12$, 11 and 14 showed a moderate decolourisation. No decolourisation was observed for 8 and 9. Thus, consortium, A, of 6, 7, 13, 15 and 16 was developed (Table 2).

In the case of Remazol black (Table 2), the isolates 6, 14 and 16 showed a high decolourisation of more than 65\%. 10 and 12 showed moderate decolourisation percentage. 4,3 and 8 showed negligible decolourisation percentage. $1,2,7,9,11,13$ and 15 showed no decolourisation. Thus, consortium, B, consisting of 6,14 and 16 was developed. 


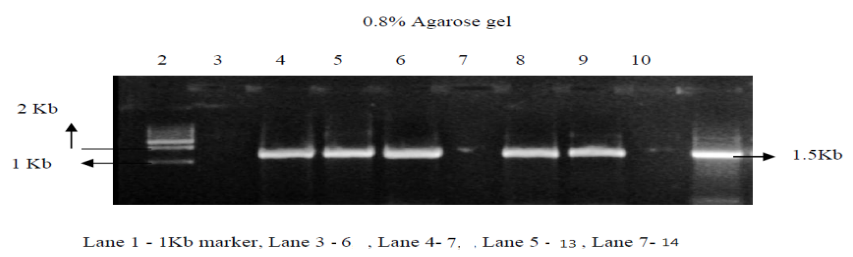

Figure 3: PCR Amplification using 16S rDNA Primers.

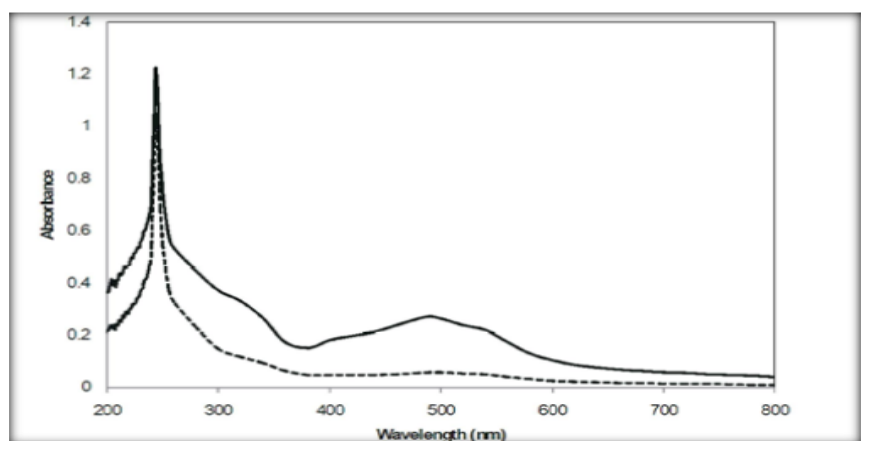

Figure 4: Changes in UV-visible spectra of Acid orange (490nm) before and after decolorization at optimum condition: $0 \mathrm{~h}(-)$ and $96 \mathrm{~h}(----)$.

\section{Characterization and identification of screened bacterial isolates}

DNA was isolated from each of the screened bacterial isolates $-6,7$, $13,15,16$ and 14 . The presence of DNA was analysed in $0.8 \%$ agarose by gel electrophoresis. The gel in Figure 2 shows the DNA isolated from the screened bacterial isolates. $16 \mathrm{~S}$ rDNA sequence of each of the samples was amplified using universal primers. The image of the gel in Figure 3 shows the amplified $16 \mathrm{~S}$ rDNA bands of the screened bacterial isolates. In comparison with $1 \mathrm{~kb}$ molecular marker, the size of amplified product was identified as $1.5 \mathrm{~kb}$. Each of the amplified products was further purified by DNA Elution kit (Bioserve Biotechnologies India Private Limited) and was subjected to cycle sequencing. The sequence obtained by cycle sequencing was subjected to BLAST analysis.

\section{Decolorization mechanism}

Decolorization of Rhodococcus was qualitatively monitored by using a UV-vis spectrophotometer. The UV- vis spectra $(200-800 \mathrm{~nm})$ of the supernatant at $4^{\text {th }}$ day of decolorization are shown in Figure 4. According to Hui Wang et al. [14] decolorization of dyes may be due to adsorption or biodegradation mechanisms. In case of adsorption the UV-vis absorption peaks decrease approximately in proportion to each other whereas if dye removal is due to biodegradation, either the major visible light absorbance peak disappears or a new peak appears. Comparing the control and sample spectrum it was understood that as Acid orange was decolorized, its absorbance peak at $490 \mathrm{~nm}$ in the visible region completely disappeared and only $203 \mathrm{~nm}$ peak in the UV range remained indicating that decolorization of Acid orange was occurred under degradation mechanism rather than surface adsorption.

\section{Effect of different dye concentration on decolourisation}

As shown in Table 3, it was found that as the concentration of dye increases, the decolourisation percentage of the dye decreases.
Taking this observation into account and also the concentration of dye discharged by the textile and dye industries, $200 \mathrm{mg} / \mathrm{l}$ of dye was selected as the optimum concentration for further studies.

\section{Effect of oxygen on the decolourisation}

As showed in Table 4, under aerobic conditions, A showed a decolourisation percentage of 85.6 after 48 hours in LB Media. Individual bacterial isolates 13 and 16 could decolourise at a faster rate compared to the rest of the isolates and the consortium. 13 and 16 also showed maximum decolourisation percentage of about 90 after 48 hours. As shown in Table 5, under aerobic conditions, in the case of Remazol black, the individual bacterial isolate 16 could decolourise at a faster rate. However, the consortium as well as each of the individual isolates showed a decolourisation percentage of more than 75 after 48 hours. Under anaerobic condition, the consortium, A, could decolourise at a faster rate than the individual bacterial isolates. In the case of Remazol Black, the consortium, B, as well as the individual bacterial isolates showed a decolourisation percentage of more than 75 after 48 hours. The individual isolate 14 could decolourise at a faster rate. Under static condition, the consortium, $\mathrm{A}$, as well as the individual bacterial isolates showed a decolourisation of more than $70 \%$. Maximum decolourisation was shown by 7 after 48 hours, followed by 13 and 15 . Consortium A could decolourise up to $92.2 \%$. However, 13 could decolourise at a faster rate. In the case of Remazol black, each of the bacterial isolates as well as the consortium, B, showed a decolourisation of more than $75 \%$. 14 showed maximum decolorisation efficiency in 48 hours. However, 16 could decolourise at a faster rate (Figures 5 and 6).

\section{Effect of carbon source}

As shown in Table 5, in the case of A, which was used against the dye, Acid orange, sodium acetate (anhydrous) showed maximum decolourisation of about $99.9 \%$. Casein, maltose and galactose showed a decolourisation percent of more than 80. In the case of B Table 6 which was used against Remazol black, decolourisation in the presence of galactose was high with a decolourisation percentage of 91 . The presence of dextrose and fructose also showed high decolourisation efficiency. Paddy straw along with beef extract acted as a nitrogen source which could bring about high decolourisation of $89.4 \%$ (Figure 7).

\section{Effect of temperature on the decolourisation}

As shown in Table 7, A showed a significant percentage of decolourisation of Acid orange between $20^{\circ} \mathrm{C}$ and $40^{\circ} \mathrm{C}$. However, maximum decolourisation of about $98 \%$ was observed at $40^{\circ} \mathrm{C}$. B showed high percentage decolourisation of Remazol black between $20^{\circ} \mathrm{C}$ and $40^{\circ} \mathrm{C}$. However, the highest percentage of decolourisation of about 97 was observed at $30^{\circ} \mathrm{C}$. Hence, the optimum temperature for the decolourisation of Mordant black by Con B was determined to be at $30^{\circ} \mathrm{C}$ (Figures 8 and 9).

\section{pH effect}

As depicted in the Table 8, A showed a maximum decolourisation of $91.1 \%$ at $\mathrm{pH} 7$. Hence, the optimum $\mathrm{pH}$ for the decolourisation

\begin{tabular}{|c|c|c|}
\hline $\begin{array}{c}\text { Dye Concentration } \\
\text { (mg/L) }\end{array}$ & $\begin{array}{c}\text { \% Decolorization of Acid } \\
\text { Orange }\end{array}$ & $\begin{array}{c}\text { \% Decolorization of Acid } \\
\text { Orange }\end{array}$ \\
\hline $\mathbf{5 0}$ & 98.75 & 99.86 \\
\hline $\mathbf{1 0 0}$ & 96.10 & 98.84 \\
\hline $\mathbf{2 0 0}$ & 95.45 & 97.36 \\
\hline $\mathbf{4 0 0}$ & 90.24 & 93.75 \\
\hline \multicolumn{3}{|c}{} \\
\hline
\end{tabular}


Citation: Shah M (2014) Exploitation of Two Consortiums in Microbial Degradation and Decolorization of Remazol Black and Acid Orange. J Pet Environ Biotechnol 5: 196. doi:10.4172/2157-7463.1000196

Page 5 of 10

\begin{tabular}{|c|c|c|c|c|c|c|}
\hline \multirow{2}{*}{ Sample } & \multicolumn{2}{|c|}{ Aerobic Condition } & \multicolumn{2}{|c|}{ Aerobic Condition } & \multicolumn{2}{|c|}{ Static Condition } \\
\hline & $24 \mathrm{hrs}$ & $48 \mathrm{hrs}$ & $24 \mathrm{hrs}$ & $48 \mathrm{hrs}$ & $24 \mathrm{hrs}$ & $48 \mathrm{hrs}$ \\
\hline 6 & $54.4 \pm 6.93$ & $68.02 \pm 4.52$ & $67.66 \pm 3.40$ & $93.1 \pm 1.42$ & $47.3 \pm 4.69$ & $73.5 \pm 1.21$ \\
\hline 7 & $79.7 \pm 5.84$ & $82.3 \pm 4.13$ & $60.97 \pm 4.08$ & $82.1 \pm 2.29$ & $69.89 \pm 4.88$ & $95.45 \pm 1.56$ \\
\hline 13 & $86.05 \pm 4.84$ & $90.07 \pm 3.57$ & $50.57 \pm 3.38$ & $87 \pm 2.31$ & $90.68 \pm 2.93$ & $92.69 \pm 2.00$ \\
\hline 15 & $85 \pm 3.08$ & $86 \pm 2.69$ & $51.95 \pm 3.25$ & $93.14 \pm 1.69$ & $58.42 \pm 1.61$ & $85.55 \pm 4.66$ \\
\hline 16 & $86 \pm 7.60$ & $91 \pm 2.08$ & $73.96 \pm 3.16$ & $92.1 \pm 1.34$ & $66.6 \pm 4.86$ & $73.37 \pm 1.34$ \\
\hline$A$ & $67 \pm 6.30$ & $85.6 \pm 3.39$ & $92.46 \pm 4.31$ & $92.9 \pm 0.191$ & $57.34 \pm 3.23$ & $92.2 \pm 1.35$ \\
\hline
\end{tabular}

Table 4: Effect of Oxygen Requirements on Decolorization of Acid Orange (200 mg/L).

\begin{tabular}{|c|c|c|c|c|c|c|}
\hline \multirow{2}{*}{ Sample } & \multicolumn{2}{|c|}{ Aerobic Condition } & \multicolumn{2}{|c|}{ Aerobic Condition } & \multicolumn{2}{|c|}{ Static Condition } \\
\hline & $24 \mathrm{hrs}$ & $48 \mathrm{hrs}$ & $24 \mathrm{hrs}$ & $48 \mathrm{hrs}$ & $24 \mathrm{hrs}$ & $48 \mathrm{hrs}$ \\
\hline 14 & $67.2 \pm 3.97$ & $77.2 \pm 1.12$ & $83.7 \pm 2.34$ & $84 \pm 3.22$ & $78.87 \pm 0.93$ & $92.07 \pm 1.47$ \\
\hline 6 & $63.03 \pm 0.93$ & $83.2 \pm 0.75$ & $55.2 \pm 1.79$ & $93 \pm 2.89$ & $67.74 \pm 1.12$ & $77.04 \pm 1.12$ \\
\hline 16 & $84.01 \pm 0.53$ & $84.03 \pm 1.02$ & $64.04 \pm 0.45$ & $79.08 \pm 0.98$ & $86.61 \pm 1.04$ & $86.06 \pm 0.89$ \\
\hline $\mathrm{B}$ & $66.35 \pm 0.53$ & $85.7 \pm 0.55$ & $61.5 \pm 0.22$ & $84.9 \pm 1.54$ & $81.69 \pm 0.09$ & $90.71 \pm 1.36$ \\
\hline
\end{tabular}

Table 5: Effect of Oxygen Requirements on Decolorization of Remazol Black (200 mg/L).

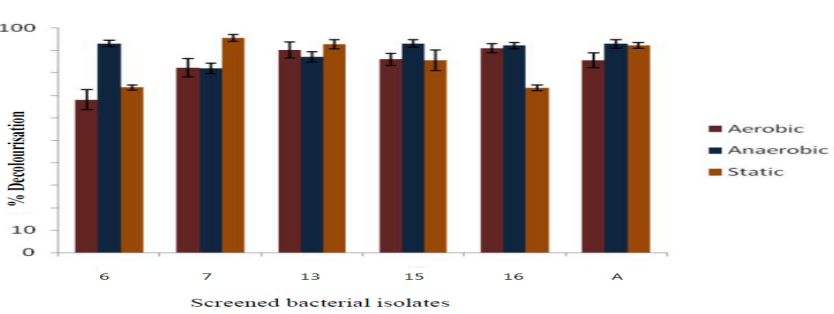

Figure 5: Effect of Oxygen Requirement on declorization of Acid Orange.

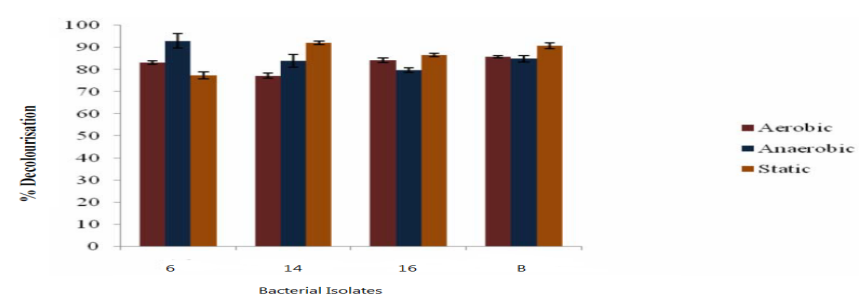

Figure 6: Effect of Oxygen Requirement on decolorization of Remazol Black.

\begin{tabular}{|c|c|}
\hline Carbon /Nitrogen sources & \%Decolourisation \\
\hline Fructose & $74.93 \pm 1.93$ \\
\hline Strach & $14.87 \pm 1.83$ \\
\hline Casein & $87.87 \pm 1.65$ \\
\hline Sodium acetate anhydrous & $99.72 \pm 1.38$ \\
\hline Yeast & $55.64 \pm 1.30$ \\
\hline Galactose & $85.12 \pm 1.64$ \\
\hline Lactose & $76.85 \pm 1.6$ \\
\hline Maltose & $80.99 \pm 1.71$ \\
\hline
\end{tabular}

Table 6: Effect of Carbon Source and Nitrogen source 313 on Acid Orange Dye degradation by Consortium A.

Acid orange by the consortium, A, was 7. Significant percentage of decolourisation of Remazol black, greater than $60 \%$ was observed in the case of $\mathrm{B}$ between $\mathrm{pH}$ ranges 6 to 7 . However, the highest decolourisation percentage of $95 \%$ was observed at $\mathrm{pH} 7$ and hence, it was taken as the optimum $\mathrm{pH}$ for the decolourisation of Remazol black by B (Figure 10).

\section{LC-MS analysis}

As shown in Figure 11 the LC-MS analysis of Acid orange degradation taken at $0^{\text {th }}$ hour and $24^{\text {th }}$ hour. The chromatogram of Acid orange ( $0^{\text {th }}$ hour) showed a peak at retention time of 7.9 with an $\mathrm{m} / \mathrm{z}$ (mass/charge) ratio of 513.01, which corresponds to the molecular weight of Acid orange. In the chromatogram taken at 24 hour incubation, the original peak disappeared and new peaks with varied retention time appeared. Mass spectra showed two distinct peaks with $\mathrm{m} / \mathrm{z}$ value of 261 and 279 , which corresponds 1-\{3-amino 5- [(aminoxy) sulphonyl] phenyl $\}$ ethanol of molecular mass of 259 and 7,8-amino-3-[(aminoxy) sulphonyl] naphthalene-1-ol of molecular mass of 281. As shown in Figure 12 the LC-MS analysis of Remazol black degradation taken at $0^{\text {th }}$ hour and $24^{\text {th }}$ hour. The chromatogram of Remazol Black ( $0^{\text {th }}$ hour) showed a peak at retention time of 8.18 with a $\mathrm{m} / \mathrm{z}$ (mass/charge) ratio of 413.16 , which corresponds to the molecular weight of Remazol Black. In the chromatogram taken at 24 hour incubation, the original peak disappeared and new peaks with varied retention time appeared. Mass spectrum showed distinct peaks with $\mathrm{m} / \mathrm{z}$ value of $381.16,245.16$ and 317.22 , which correspond to 1',1-diazene-1,2-diyldinaphthalen-2-ol-sulphide ion of molecular mass 381 1,1'-diazene-1,2-diyldinaphthalen-2-ol of molecular mass 245 and sodium-4-amino-naphthalene-1-sulphonate of molecular mass 317.

\section{Discussion}

The decolourisaton reaction of the azo dyes by the bacteria is the structure of azo dye. Colour removal is related to the number of azo bonds in the dye molecule. Dyes with simple structure and low molecular weights exhibit greater decolourisation in the presence of bacteria, whereas colour removal is more difficult with highly substituted high molecular weight dyes [15]. In this study, total 6 bacterial colonies were screened from the 16 bacterial isolates obtained during serial dilution. Each of the bacterial colonies exhibited different decolourisation efficiency. Hence, it was inferred that the colour removal process is also dependent on the potential of the bacteria to attack the dye molecule leading to its decolourisation. In 2002, Navitan Blue S5R was tested for decolourisation with 5 different bacterial species - Pseudomonas aeruginosa, Pseudomonas fluorescens, Pseudomonas putida, Flavobacterium multivorum and Ochrobacterium anthropi. Pseudomonas aeruginosa was the best degrader, able to degrade up to $1200 \mathrm{mg} / \mathrm{l}$ and was used for further studies [16]. Another report stated the isolation of four bacterial species that were capable of growing 
Citation: Shah M (2014) Exploitation of Two Consortiums in Microbial Degradation and Decolorization of Remazol Black and Acid Orange. J Pet Environ Biotechnol 5: 196. doi:10.4172/2157-7463.1000196

Page 6 of 10

\begin{tabular}{|c|c|}
\hline Carbon /Nitrogen sources & \% Decolourisation \\
\hline Maltose & $91.5 \pm 0.55$ \\
\hline Dextrose & $81.2 \pm 1.20$ \\
\hline Galactose & $91.7 \pm 0.45$ \\
\hline Yeast extract & $60.83 \pm 0.56$ \\
\hline Lactose & $26.9 \pm 2.93$ \\
\hline Casein & $74.05 \pm 0.79$ \\
\hline Fructose & $89.37 \pm 1.35$ \\
\hline Starch & $15.05 \pm 4.51$ \\
\hline Ammonium sulphate & $4.2 \pm 0.77$ \\
\hline Paddy straw & $70.6 \pm 3.29$ \\
\hline Sodium nitrate & $42.6 \pm 0.76$ \\
\hline Beef extract & $71.6 \pm 1.73$ \\
\hline Sodium acetate & $0 \pm 0.22$ \\
\hline Straw+Beefextract & $84.8 \pm 2.88$ \\
\hline
\end{tabular}

Table 7: Effect of carbon/nitrogen source 333 on decolourisation of Remazol black by Consortium B.

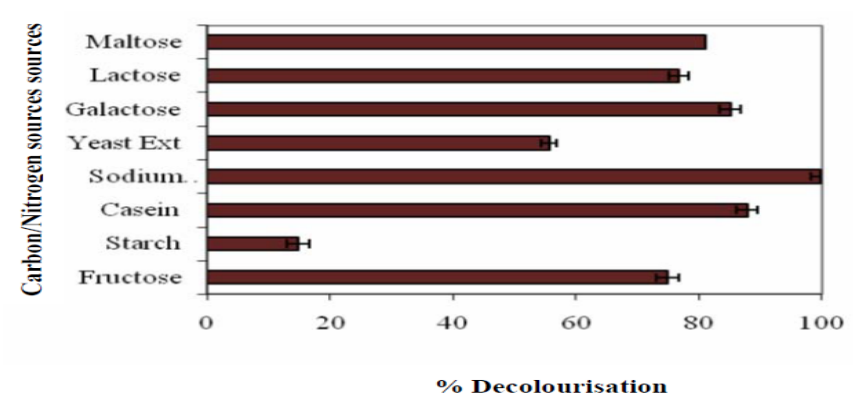

Figure 7: Effect of Carbon and Nitrogen Source.

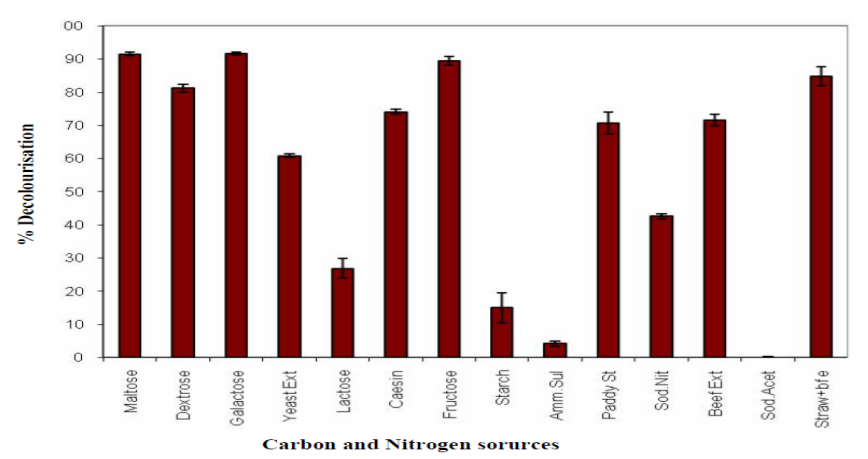

Figure 8: Effect of carbon/nitrogen source on decolourisation of Remazol black by consortium $\mathrm{B}$.

on Methyl red, of which one of them Vibrio logei showed the highest Methyl red degrading activity [17].

From the decolourisation assay results obtained, two consortia were developed and were used for further studies. Mixed culture or consortium has the capacity to decolourise at a higher rate in comparison to the individual bacterial colonies. This is due to the synergistic effect of the bacterial isolates in dye decolourisation. It has been stated that the individual strains may attack the dye molecule at different positions or may use the decomposition products produced by the other strain, thereby, bringing about synchrony in decolourisation of the azo dye [18]. A consortium GB containing Galactomyces

geotrichum and Bacillus sp. could decolourise Brilliant Blue $\mathrm{G}$ to a large extent [19]. The species identified in our experiment by this analysis are Pseudomonas sp., Alcaligens sp., Proteobacterium, Rhodococcus sp, Bacillus sp and Stenotrophomonas. It has been reported earlier that Pseudomonas aeruginosa has the capacity to degrade Navitan Fast Blue [19]. Acinetobacter calcoaceticum has been reported to decolourise diazo dye, Direct Brown MR [20]. Proteobacterium has been reported to decolourise Indigo carmine [21]. In both the cases, the percentage decolourisation of the dye decreases with increase in dye concentration. The optimum concentration of the dye for both the consortia was zeroed in to $200 \mathrm{mg} / \mathrm{l}$ and was maintained for the rest of the decolourisation experiments. The decrease in percent decolourisation with increase in dye concentration can be attributed to reasons such as the toxic nature

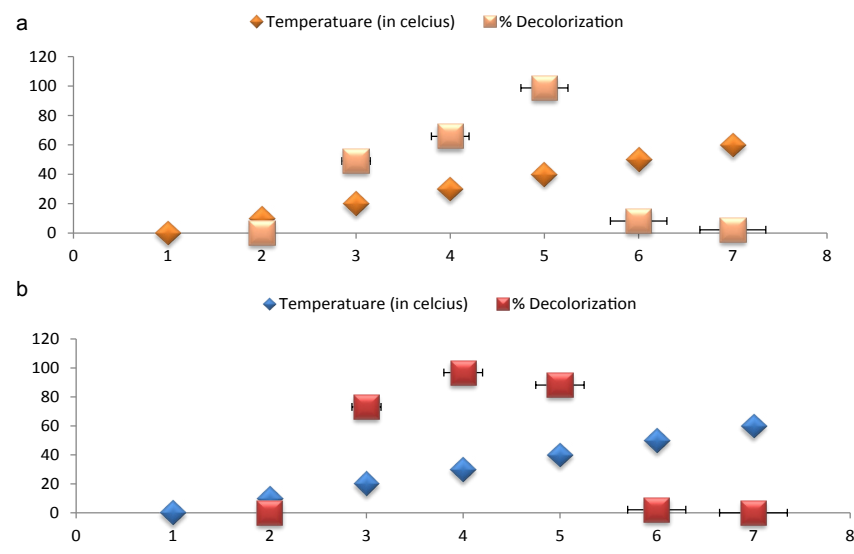

Figure 9: (a) Effect of Temperature of decolorization of Acid Orange by $A$ (b) Effect of Temperature of decolorization of Remazol Black by $\mathrm{B}$.

\begin{tabular}{|c|c|c|}
\hline Temperature $\left({ }^{\circ} \mathbf{C}\right)$ & $\begin{array}{c}\text { \% Decolorization of Acid } \\
\text { Orange by A }\end{array}$ & $\begin{array}{c}\text { \% Decolorization of } \\
\text { Remazol Black by B }\end{array}$ \\
\hline 10 & $0 \pm 1.18$ & $0 \pm 0.09$ \\
\hline 20 & $49 \pm 0.728$ & $73.12 \pm 2.9$ \\
\hline 30 & $65.8 \pm 1.52$ & $96.82 \pm 1.18$ \\
\hline 40 & $98.7 \pm 2.12$ & $88.2 \pm 1.108$ \\
\hline 50 & $8.20 \pm 1.18$ & $2.10 \pm 1.42$ \\
\hline 60 & $2.21 \pm 1.86$ & $0 \pm 0.08$ \\
\hline
\end{tabular}

Table 8: Effect of Temperature on decolorization of two dye by two consortium.
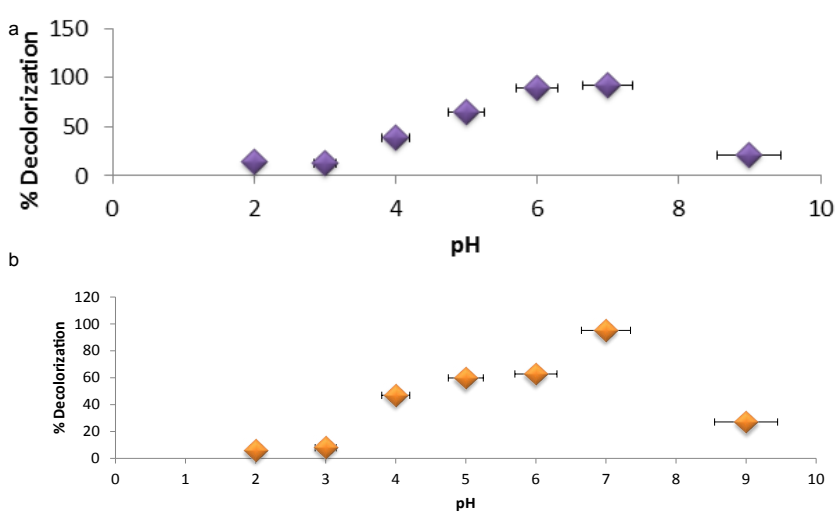

Figure 10: (a) Effect of $\mathrm{pH}$ on decolorization of Acid orange by $\mathrm{A}$ (b) Effect of $\mathrm{pH}$ on decolorization of Remazol Black by $\mathrm{B}$ 
a

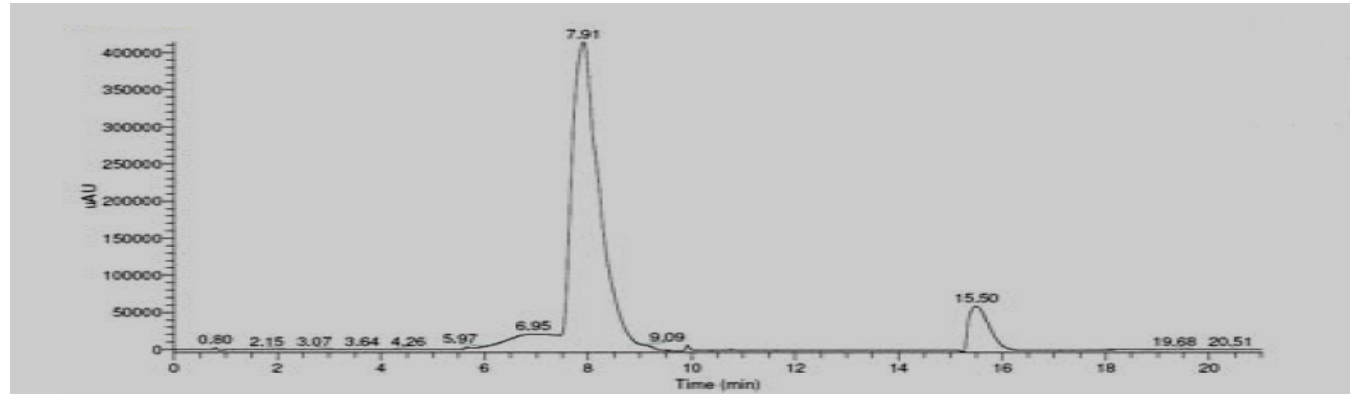

b

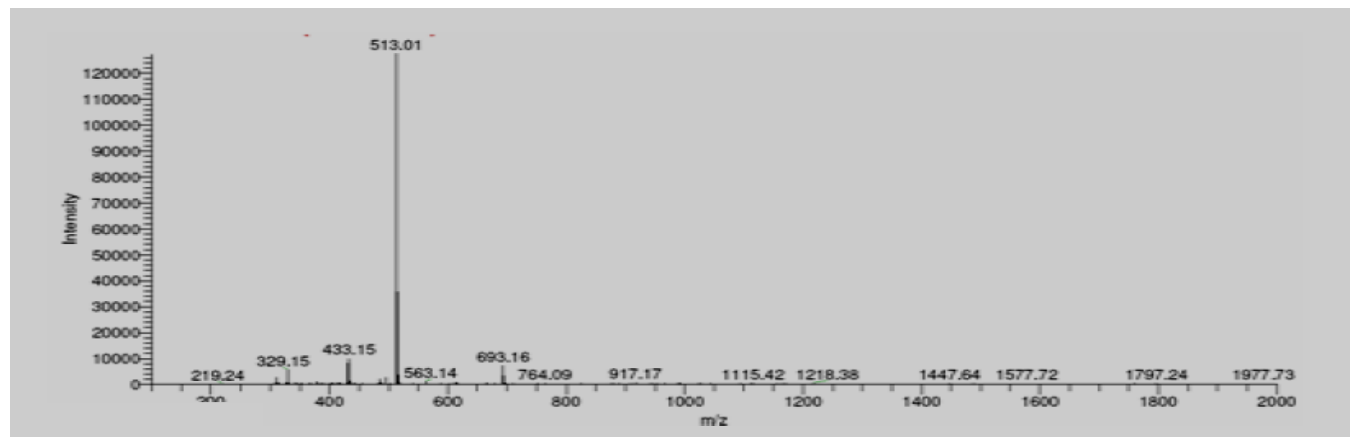

c

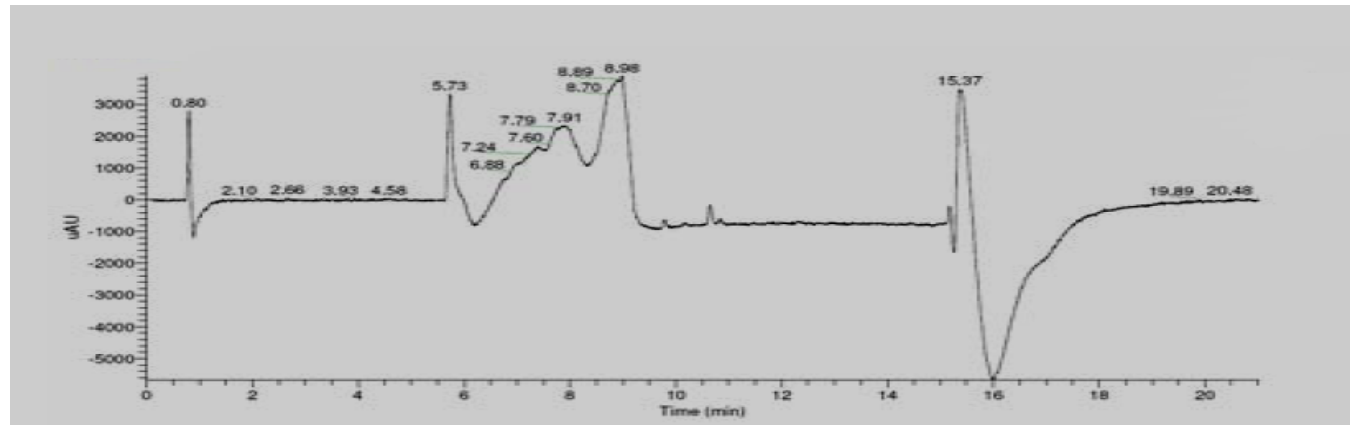

d

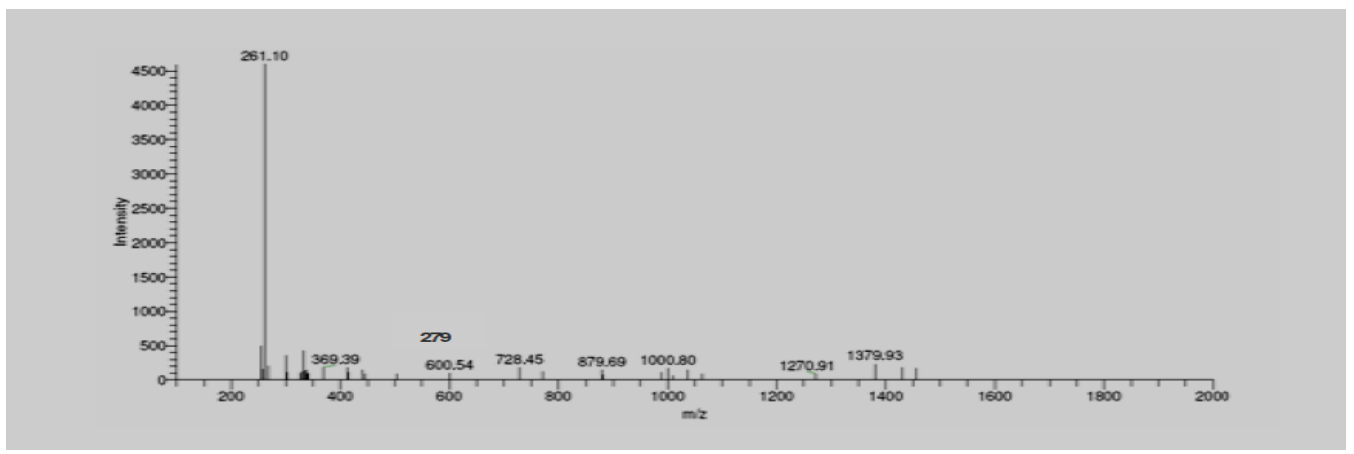

Figure 11: (a) Chromatogram of Acid Orange at 0 Hour

(b) Mass Spectrum of Acid Orange at 0 Hour

(c) Chromatograph of Acid Orange after 24 Hour decolorized culture

(d) Mass Spectrum of Acid Orange after 24 Hour decolorized culture

of the dye [19], depletion of carbon source in vitro, thereby pressurizing the bacteria to survive with the dye as its sole source of carbon.

Dyes are deficient in carbon source [22] and hence, it is difficult for the bacteria to utilize it as its sole source of carbon for its survival. Higher the dye concentration, the longer the time required to remove the colour. In this part of decolourisation experiment, it was inferred that static condition was the best condition for both the consortia. Though anaerobic condition showed better results, static condition was chosen for further studies owing to difficulties in maintaining the culture. During the dye reduction stage, if the extra cellular environment is aerobic, the high redox potential electron acceptor, oxygen, may inhibit the dye reduction mechanism. This is because the electron liberated from the oxidation of electron donors by the cells are preferentially used 
a

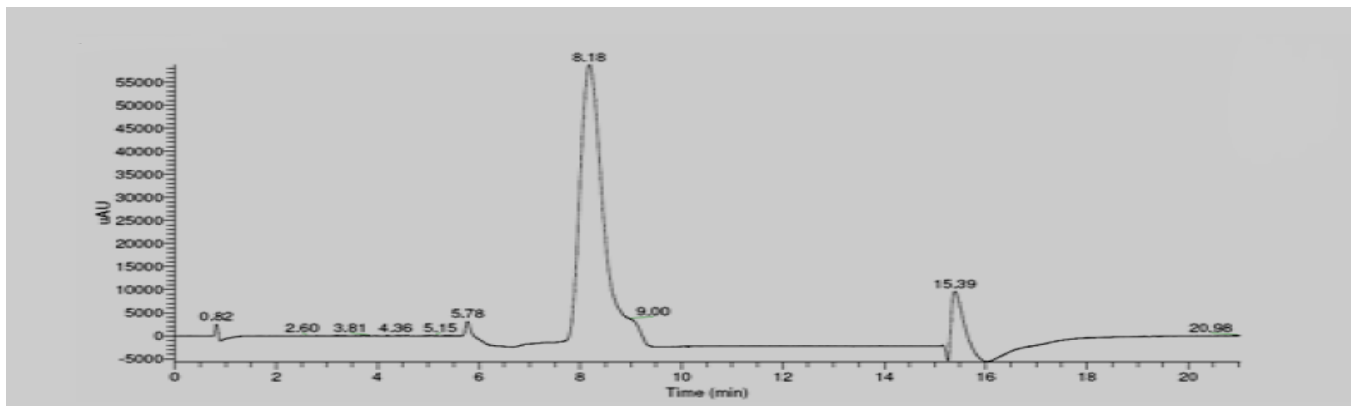

b

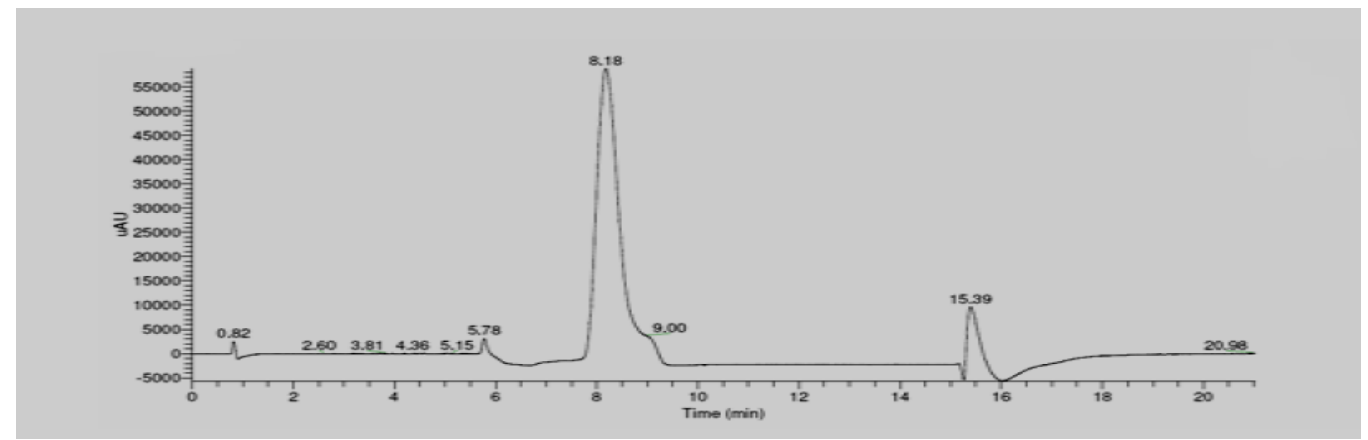

C

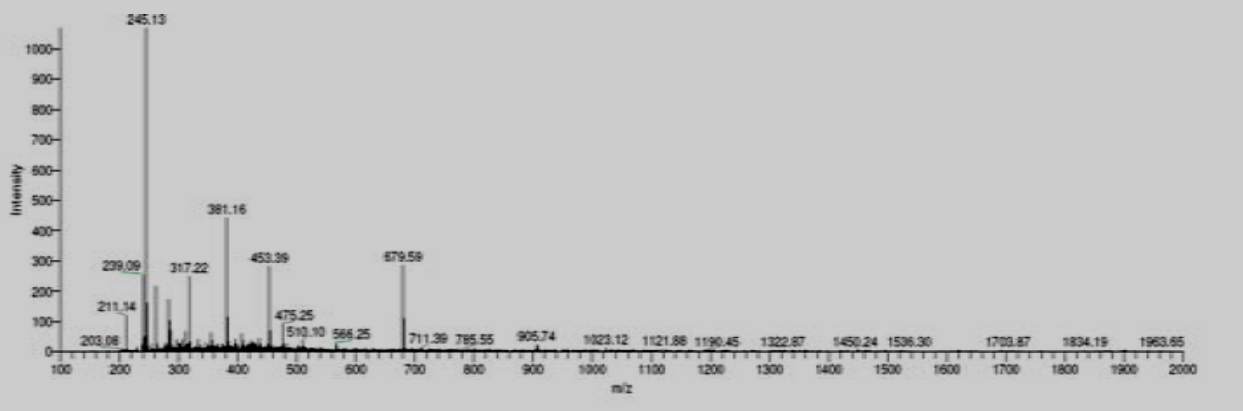

d

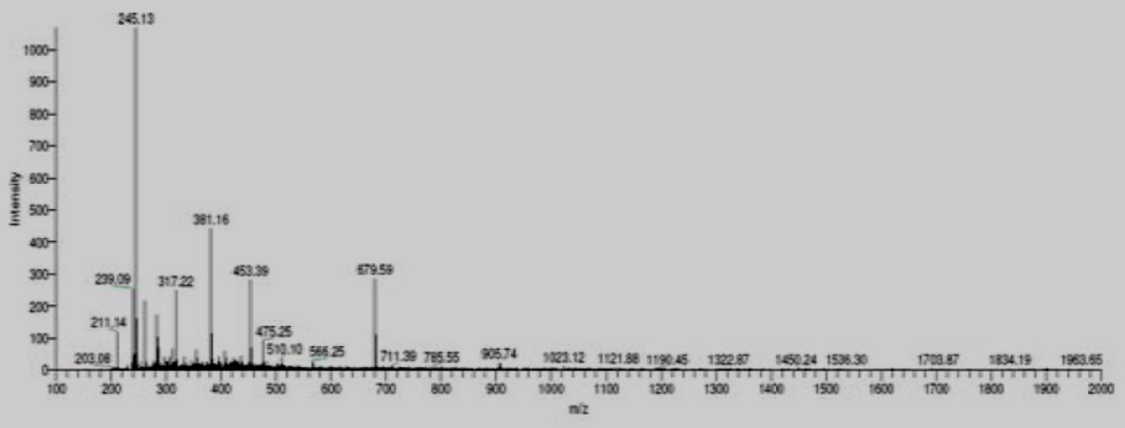

Figure 11: (a) Chromatogram of Remazol black at $0^{\text {th }}$ hour

(b) Mass spectrum of Remazol black at $0^{\text {th }}$ hour

(c) Chromatogram of 24 hour decolourised culture of Remazol black

(d) Mass spectrum of 24 hour decolourised culture of Remazol Black e) Pathway of degradation

to reduce oxygen rather than the azo dye, and the reduction product, water, is not a reductant [23]. Also, the postulated intermediates of the dye reduction reaction, which include the hydrazine form of the dye and the azo anion free radical form of the dye, tend to be reoxidised by molecular oxygen [24].
It has been stated that however, the inhibition of azo dye reduction under aerobic conditions tends only to be a temporary effect rather than an irreversible effect. If the air is replaced with oxygen free nitrogen, the reducing activity is restored and occurs at a similar rate to that which was observed under continuous anaerobic conditions. It has been suggested 
that if a sequential anaerobic-aerobic system is employed for wastewater treatment, the amines can be mineralized under aerobic conditions by a hydroxylation pathway involving a ring opening mechanism [25]. In both the decolourisation studies, lack of carbon supplements in minimal media did not show significant decolourisation. This can be attributed to the fact that the bacteria utilize the carbon sources to release $\mathrm{NADH}$, which are the co-factors for the enzyme, azoreductase. Azoreductase brings about reductive cleavage of the azo bond in dyes, thereby causing decolourisation. Minimal media, devoid of any carbon source, hence, does not act as an effective medium for the bacteria to bring about the decolourisation of dyes. It was concluded that neither of the individual bacterial isolates nor the consortia could decolourise utilizing the dye as its sole source of carbon for its growth.

As stated earlier, dyes are deficient sources of carbon. It has been stated that the oxidation of organic electron donors and/or hydrogen is coupled to the colour removal process. The addition of electron donors such as glucose or acetate ions apparently stimulates the reductive cleavage of azo bonds [26]. The thermodynamics of the different electron donors are different and therefore, the reaction rate is likely to get influenced by the type of electron donor. It was reported that the organic nitrogen sources can regenerate $\mathrm{NADH}$, which acts as an electron donor for the reduction of azo dyes by microorganisms .However, in some cases, the addition of carbon sources seemed to be less effective to promote the decolourisation, probably due to the preference of the cells in assimilating the added carbon sources over using the dye compound as the carbon source [27]. The addition of nitrogen also has another advantage in tannery industries. Ammonium salts are used in the delimiting stage, (one of the unit operations in leather processing) and ammonium salts are one of the constituent of tannery effluents. Since the tannery effluent also contains excessive amount of organic nitrogen, mainly from the hides and skins during leather manufacture, the combined effect of the effluent treatment can have considerable effect on the decolourisation by the biomass [19].

The temperature required to produce the maximum rate of colour removal tends to correspond with the optimum cell culture growth temperature as well as the optimum activity of enzyme within $35^{\circ} \mathrm{C}$ to $45^{\circ} \mathrm{C}$. The dye decolourisation efficiency is negligible at low temperature $\left(10^{\circ} \mathrm{C}\right.$ and $\left.20^{\circ} \mathrm{C}\right)$ due to inactive state of the enzyme. There is negligible decolourisation at high temperature (greater than $45^{\circ} \mathrm{C}$ ). The decline in colour removal activity can be attributed to the loss of cell viability or to the denaturation of the azoreductase enzyme [28]. However, it has been reported that with certain whole bacterial cell preparations, the azoreducatase enzyme is relatively thermo stable and can remain active up to $60^{\circ} \mathrm{C}$, over a short period of time [22]. The isolation of a thermo stable azoreductase, from Bacillus sp. strain SF, has been reported which showed high decolourisation of dyes at a temperature of $80^{\circ} \mathrm{C}$ [22]. The optimum $\mathrm{pH}$ of decolourisation of dyes by both the consortia is 7 . This may be due to the fact that soil bacteria require a $\mathrm{pH}$ range of 6.6-6.8 for their growth.

The rate of colour removal tends to decrease rapidly at strongly acid or strongly alkaline $\mathrm{pH}$ values. Biological reduction of azo bonds can result in an increase in the $\mathrm{pH}$, due to the formation of aromatic amine metabolites, which are more basic than the original azo compound [29]. The repeated use of microorganisms is important in the commercial point of view. The reduction in dye decolourisation by both the consortia could be attributed to reasons like depletion of carbon source required for the bacterial growth, production of toxic metabolites by the bacteria and reduction in the number of viable cells [30]. The reductive cleavage of azo bonds releases mutagenic aromatic amines, which can damage the cells. The phytotoxic effect of the aromatic amines has also been studied [31].

\section{Conclusion}

In this study, two different consortia were developed, which could degrade Acid orange and Remazol black. The consortium, A, constituting Pseudomonas sp., Alcaligens sp, Stenotrophomonas sp., Proteobacterium and Rhdodococcus, could decolourise $200 \mathrm{mg} / \mathrm{l}$ of Acid orange in the presence of anhydrous sodium acetate under static condition at $\mathrm{pH} 7$ and temperature of $40^{\circ} \mathrm{C}$ within 48 hours. The consortium B, constituting Bacillus, Proteobacterium and Rhodococcus showed high decolourisation of $200 \mathrm{mg} / \mathrm{l}$ of Remazol black in the presence of galactose and a combination of straw and beef extract under static condition at $\mathrm{pH} 7$ and temperature of $30^{\circ} \mathrm{C}$ within 48 hours. The study of degradation of Acid orange shows the action of azoreductase leading to the generation of 1-\{3-amino 5- [(aminoxy) sulphonyl] phenyl\} ethanol and 7, 8-amino-3-[(aminoxy) sulphonyl] napthalen-1-ol. LC-MS analysis on the degradation of Remazol black shows the presence of 1.1'-diazene-1,2-diyldinapthlen-2-ol, formed as a result of desulphonation and sodium-4-amino-naphthalene-1sulphonate, formed as a result of azoreductase activity. In both the studies, azoreductase was the key enzyme causing dye degradation.

\section{References}

1. Maulin PS, Patel KA, Nair SS, Darji AM, Shaktisinh M (2013) Optimization of Environmental Parameters on Decolorization of Remazol Black B Using Mixed Culture. Am J Microbiol Res 3: 53-56

2. Maulin PS, Patel KA, Nair SS, Darji AM (2013) Microbial Decolorization of Methyl Orange Dye by Pseudomonas sp.ETL-M. Int J Environ Bioremed and Biodegrad 2: 54-59.

3. Maulin PS, Patel KA, Nair SS, Darji AM (2013) Microbial Degradation and Decolorization of Reactive Orange Dye by Strain of Pseudomonas Sp. Int $J$ Environ Bioremed and Biodegrad 1: 1-5.

4. Maulin PS, Patel KA, Nair SS, Darji AM (2013) An Innovative Approach to Biodegradation of Textile Dye (Remazol Black) by Bacillus sp. Int J Environ Bioremed and Biodegrad 2: 43-48.

5. Maulin PS (2013) Microbial Degradation of Textile Dye (Remazol Black B) by Bacillus sp. J App \& Environ Microb1: 6-11

6. Maulin P S, Patel KA, Nair SS, Darji AM (2014) Microbial Degradation and Decolourization of Reactive Dyes by Bacillus Sp. Am J Microbiol Res 1: 16-23.

7. Maulin PS, Patel KA, Nair SS, Darji AM (2013) Environmental Bioremediation of Dyes by Pseudomonas aeruginosa ETL-1 isolated from Final Effluent Treatment Plant of Ankleshwar. Am J Microbiol Res 4: 74-83.

8. Maulin PS, Patel KA, Nair SS, Darji AM (2013) Microbial Decolorization of Textile Dyes by Bacillus sp. ETL-79: An Innovative Biotechnological Aspect to Combat Textile Effluents. Am J Microbiol Res 3: 57-61.

9. Maulin PS, Patel KA, Nair SS, Darji AM (2013) Isolation, Identification and Screening of Dye Decolorizing Bacteria. Am J Microbiol Res 4: 62-70.

10. Maulin PS, Patel KA, Nair SS, Darji AM, Shaktisinh M (2013) Microbia Degradation of Azo Dye by Pseudomonas spp. MPS-2 by an Application of Sequential Microaerophilic and Aerobic Process. Am J Microbiol Res 43: 105112.

11. Maulin PS (2014) Microbiological Removal of Phenol by an Application of Pseudomonas spp. ETL: An Innovative Biotechnological Approach Providing Answers to the Problems of FETP. J Appl Environ Microbiol 2: 6-11.

12. Maulin PS, Patel KA, Nair SS, Darji AM (2014) Decolorization of Remazol Black $B$ by Three Bacterial Isolates. Int J Environ Bioremed and Biodegrad 1: 44-49.

13. Yatome C, Ogawa T, Koga D, Idaka E (1981) Biodegradation of Azo and triphenylmethane dyes by Pseudomonas pseudomallei. J Society.dyers colorist 97: 166-169.

14. Wang H, Su JQ, Zheng XW, Tian Y, Xiong XJ (2009) Bacterial Decolorization and Degradation of the Reactive dye Reactive Red180 by Citrobacter sp. CK3. Int Biodeter Biodegr 63: 395-399. 
Citation: Shah M (2014) Exploitation of Two Consortiums in Microbial Degradation and Decolorization of Remazol Black and Acid Orange. J Pet Environ Biotechnol 5: 196. doi:10.4172/2157-7463.1000196

Page 10 of 10

15. Pearce Cl, Lloyd JR, Guthrie JT (2003) Removal of Colour from Textile Wastewater using Whole Bacterial Cells: A Review. Dyes Pigments 58: 179196.

16. Kolekar YM, Pawar SP, Gawai KR, Lokhande PD, Shouche YS, et al. (2008) Decolorization and Degradation of Disperse Blue 79 and Acid Orange 10 by Bacillus fusiformis KMK5 Isolated from the Textile Dye Contaminated soil. Bioresource Technol 99: 8999-9003.

17. Adedayo O, Taylor C, Anderson WA, Moo-Young M (2004) Decolourisation and Detoxification of Methylred by Aerobic Bacteria from a Wastewater Treatment Plant. World J Microb Biot 20: 545-550.

18. Asad S, Amoozegar MA, Pourbabaee AA, Jadhav UU, Dawkar VV et al. (2007) Biodegradation of Direct Red Decolorization of Textile Azodyes by Newly Isolated 5B, A Textiledye by Newly Isolated Comamonas sp. Halophilic and Halotolerant Bacteria. J Hazard Mat 158: 507-516.

19. Sheetal UJ, Mital U, Anuradha N, Sanjay P (2008) Decolourisation of Brilliant Blue G Dye Mediated by Degradation of the Microbial Consortium of Galactomyces geotrichum and Bacillus sp. J Chin Inst Chem Eng 39: 563-570.

20. Nachiyar VC, Susheela Rajkumar G (2003) Degradation of a Tannery and Textile Dye,: Navitan Fast Blue S5R by Pseudomonas aeruginosa. World J Microb Biot 19: 609- 614

21. Gajanan G, Sheetal J, Vishal D, Sanjay G (2008) Biodegradation of Diazodye Direct Brown MR by Acinetobacter calcoacetticum NCIM 2890. Int J Biodeter and Biodegr 164: 296-300.

22. Forgacs E, Cserhati T, Oros G (2004) Removal of Synthetic Dyes from Wastewaters: A Review. Environ Int 30: 953-971.
23. Saha P, Chakrabarti T (2006) Emticicia oligotrophica, A new member of the family 'Flexibacter' phylum Bacteriodetes. IJSEM 56: 991-995.

24. Pandey G, Paul D, Jain RK (2003) Branching of o-nitrobenzoate Degradation Pathway in Arthrobacter protophormiae RKJ100: Identification of new intermediates. FEMS Microbiol Lett 229: 231-236.

25. Mazaheri AM, Rostami K, Shahvali M, Jadhav SU, Kalme SD (2001) Decolorization of textile waste Biodegradation of Methyl red by water by Phanerochaete chrysosporium.,Galactomyces geotrichum MTCC 1360. J Biodeter Biodegr 62: 135-142.

26. Mohan SV, Prasad KK, Rao NC, Kolekar YM, Sarma PN (2005) Acid azo dye degradation by free and immobilized horseradish peroxidase (HRP) catalyzed process. Chemosphere 58: 1097-1105.

27. Chang J Lin C (2001) Decolorization Kinetics of a Recombinant Escherich Coli Strain Harboring Azodye-Decolorizing Determinants from Rhodococcus sp. Biotechnol Lett 23: 631-636.

28. Jadhav UU, Dawkar VV, Ghodake GS, Govindwar SP (2008) Biodegradation of Direct Red 5B,A textile dyes by newly isolated Comamonas sp. UVS. J Hazard Mater 158: 507-516.

29. Gurusharan S, Neena C, Rashmi G, Prince S (2007) A pH-stable laccase from alkali-tolerant $\mathrm{Y}$-proteobacterium JB: Purification, characterization and indigo carmine degradation. Enzyme Microbiol Technol 41: 794-799.

30. Padmavathy S, Sandhya S, Swaminathan K, Subramanium YV, Chakrabart T, et al. (2003) Aerobic Decolourisation of Reactive Azodyes in Presence of Various Co-substrates. Chem Biochem Eng 17 : 147-151.

31. Yoo ES, Libra J, Adrain L (2001) Mechanism of Decolourisation of Azo dye in an Anaerobic Mixed Culture. J Environ Eng 127: 844-849. 